\title{
APPLICATION OF SURFICIAL EXPLORATON METHODS IN THE LAKE TIMISKAMING KIMBERLITE FIELD, CANADA
}

\author{
M. Beth McClenaghan ${ }^{1}$, Ingrid M. Kjarsgaard ${ }^{2}$, Bruce A. Kjarsgaard ${ }^{1}$ and Paul A. Sobie ${ }^{3}$ \\ ${ }^{1}$ Geological Survey of Canada, Canada; ${ }^{2}$ Mineralogical Consultant, Canada; ${ }^{3}$ MPH Consulting Ltd., Canada
}

\section{KIMBERLITE GEOLOGY}

The Lake Timiskaming kimberlite field is $80 \mathrm{~km}$ south of the Kirkland Lake kimberlite field in northeastern Ontario (Fig. 1) and contains 15 kimberlite pipes emplaced between 134 and $155 \mathrm{Ma}$ along the broadly northwest trending Lake Timiskaming Structural Zone. The most common kimberlite facies found in the pipes are tuffisitic kimberlite breccia and hypabyssal kimberlite, indicating that they have been eroded to the diatreme and root zones, comparable to kimberlite pipes in the Kimberley region of South Africa. They penetrate various lithologies of the Archean Abitibi Greenstone Belt and overlying Paleoproterozoic sedimentary rocks. Armstrong and McCracken (1996) estimated on the basis of crustal xenoliths found in the kimberlites that the present land surface was covered by an additional $700 \mathrm{~m}$ of Paleozoic carbonate sedimentary rocks at the time of emplacement. Most bedrock in the region is covered by glacial sediments ranging in thickness from a few to $40 \mathrm{~m}$. Kimberlite, being relatively soft, was differentially eroded by preglacial weathering and glacial scouring and can subcrop up to $20 \mathrm{~m}$ below the surrounding bedrock surface. Subsequently, most Lake Timiskaming kimberlites were covered by Quaternary age glacial sediments and have no surface expression.

The kimberlites, in general, contain abundant macrocrystic garnet, Mg-ilmenite, chromite and olivine, and much less $\mathrm{Cr}$-diopside. Mg-ilmenite compositions are different for each pipe such that within the field, Mgilmenite compositions can be used to distinguish between dispersal trains from different kimberlites. Compared to the Kirkland Lake kimberlite field, Mg-ilmenite compositions for Lake Timiskaming kimberlites are more $\mathrm{MgO}$ and Cr-rich (reduced). Chromite compositions extend to the diamond inclusion and diamond intergrowth field in most pipes, but compositions $>61 \mathrm{wt} . \% \mathrm{Cr}_{2} \mathrm{O}_{3}$ are rare. Garnet populations are dominated by garnets from fertile garnet lherzolite and by megacrysts. Subcalcic harzburgitic to dunitic garnets comprise $<1 \%$ of the garnet populations. Garnets from potentially diamondiferous eclogite (Group I eclogite) are very rare and were only identified in the Gravel and Guigues kimberlites (Sage, 1986). Cr-diopside is much less abundant that the other indicator minerals and is mainly from coarse to sheared lherzolite. Olivine compositions fall into two (overlapping) groups: kimberlitic olivine phenocrysts (generally with $\mathrm{Fo}<90$ and $\mathrm{NiO} \leq 0.25$ wt.\%) and peridotitic olivine (generally $\mathrm{Fo}>90$ and $\mathrm{NiO} \geq 0.25$ wt.\%). The diamond potential of the known kimberlites, based on indicator mineral chemistry, is inferred to be low compared to kimberlites from the Lac de Gras area, NWT, however the Lake Timiskaming region is considered to have the potential to host diamondiferous kimberlites.

\section{SURFICIAL EXPLORATION METHODS}

Glacial sediment thickness varies from $40 \mathrm{~m}$ at the Bucke kimberlite to $<0.1 \mathrm{~m}$ at the McLean and BBB kimberlites. Because the exotic cover is of variable thickness, kimberlite exploration in the region utilizes both geophysical and drift prospecting (kimberlite boulders, indicator minerals in till, glaciofluvial and stream sediments) methods. Clastic dispersal patterns associated with the kimberlites are the net result of: 1) glacial transport by three phases of ice flow across the region (Fig. 1) towards the southwest, south, and, finally, southeast (Veillette and McClenaghan, 1996; McClenaghan et al., 2001); 2) glaciofluvial transport in meltwater channels during the final phase of glaciation; and/or 3) subsequent fluvial transport in rivers and streams. Kimberlites boulders and cobbles are common in pebble to boulder-sized gravel facies of the Sharp Lake and Lac Baby eskers (Fig. 3). Indicator mineral chemistry and relative abundance of indicator minerals, as well as $\mathrm{U}-\mathrm{Pb}$ age determinations (McClenaghan et al, 2002), indicate that the boulders are derived from as yet undiscovered kimberlites in the region.

Exploration companies have successfully used regionalscale indicator mineral surveys, sampling till and esker sands, to identify areas for more detailed sampling and to prioritize geophysical targets for further evaluation. The silty sand (coarse) texture and high local bedrock component of the till in the region makes it the optimum sampling medium for indicator mineral surveys. Discrete dispersal patterns are best defined by the abundance of indicator minerals in the 0.25 to $0.5 \mathrm{~mm}$ nonferromagnetic heavy mineral fraction of till. Dispersal trains vary from narrow ribbon-shapes produced by a single phase of ice flow, such as the Cr-pyrope and $\mathrm{Cr}$ diopside-rich train extending $15 \mathrm{~km}$ southwest of the 95-2 kimberlite, to broad fan-shapes formed by two or three phases of ice flow, such as the Cr-pyrope and $\mathrm{Mg}$ ilmenite-rich train extending $8 \mathrm{~km}$ south of the Bucke 


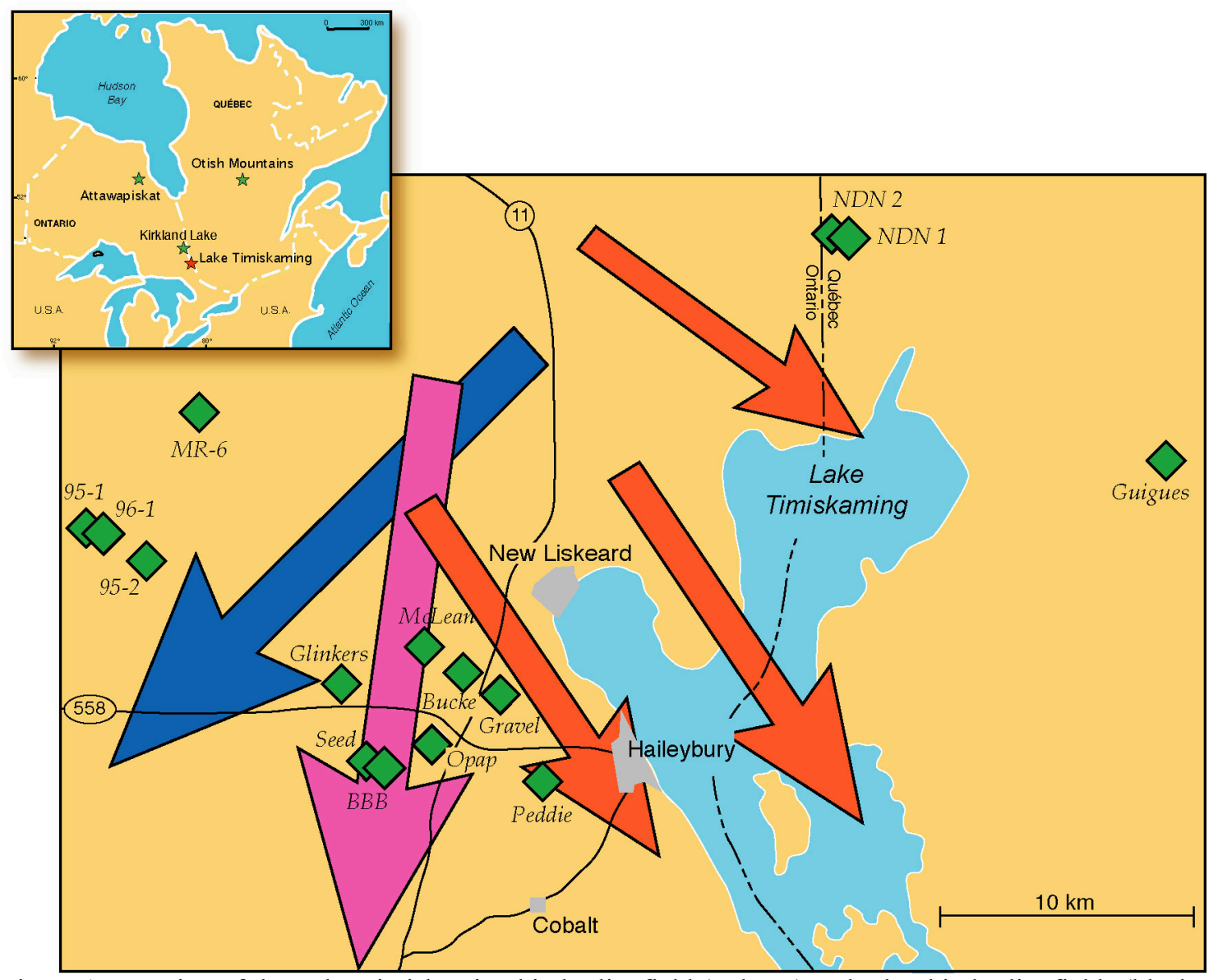

Figure 1. Location of the Lake Timiskaming kimberlite field (red star) and other kimberlite fields (black stars) in northeastern Ontario, location of kimberlites within the Lake Timiskaming field and regional ice flow directions (blue arrow $=$ oldest ice flow; red arrow= youngest ice flow).

and Gravel kimberlites. Till just down-ice of a kimberlite contains 100 's to 1000 's of indicator minerals in a $10 \mathrm{~kg}$ sample, the total and relative abundance of which reflects indicator mineral content of the kimberlite. For example, olivine and Mg-ilmenite-rich till overlying and immediately down ice of the Peddie kimberlite reflects the dominance of olivine and $\mathrm{Mg}$-ilmenite in this kimberlite (McClenaghan et al., 1999). Because chromite and $\mathrm{Cr}$-diopside occur in other local ultramafic rocks, they are less useful as indicator minerals. Till geochemistry also can be a useful tool for kimberlite exploration in the region. Pathfinder elements such as Ta, $\mathrm{Nb}, \mathrm{Cr}, \mathrm{Ni}, \mathrm{Sr}, \mathrm{P}_{2} \mathrm{O}_{5}$, and LREE in the $<0.063 \mathrm{~mm}$ (silt+clay) and the 0.5 to $2.0 \mathrm{~mm}$ (coarse sand) fractions of the till matrix best define kimberlite dispersal down-ice, as has been demonstrated for the Peddie (McClenaghan et al., 1999, 2002) and BBB kimberlites.

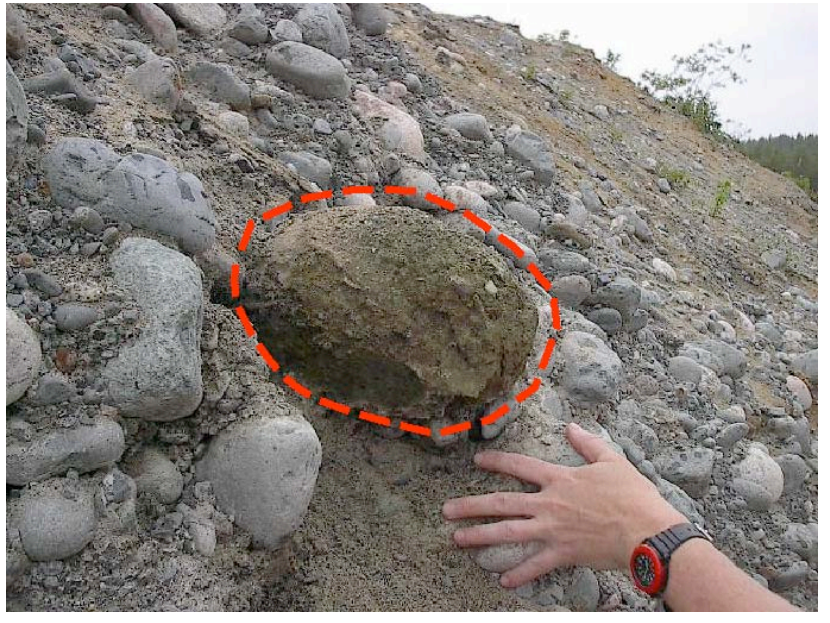

Figure 2. Kimberlite boulder in esker gravel. 


\section{REFERENCES}

Armstrong, D.K., McCracken, A.D., 1996. Summary of paleontological report on xenoliths from Kirkland Lake and Lake Timiskaming area kimberlite pipes. In: Kimberlites of the Lake Timiskaming structural zone. Ontario Geological Survey, Open File Report 5937, 377-382.

McClenaghan, M.B., Kjarsgaard, B.A., Kjarsgaard, I.M., R.C. Paulen, Stirling, J.A., 1999. Mineralogy and geochemistry of the Peddie kimberlite and associated glacial sediments, Lake Timiskaming, Ontario. Geological Survey of Canada, Open File 3775, 190 p.

McClenaghan, M.B., Kjarsgaard, I.M., Kjarsgaard B.A., 2001. Reconnaissance-scale till survey in the New LiskeardTemagami-region, Ontario: kimberlite indicator mineral and geochemistry. Geological Survey of Canada, Open File 4086.

McClenaghan, M.B., Kjarsgaard, B.A., Kjarsgaard, I.M., 2002 Indicator mineral content and geochemistry of till around the Peddie kimberlite, Lake Timiskaming, Ontario. Geological Survey of Canada Open File 4262, 132 p..

Sage, R.P., 1996. Kimberlites of the Lake Timiskaming structural zone. Ontario Geological Survey, Open File Report 5937, 435 p.

Veillette, J.J., McClenaghan, M.B., 1996. Sequence of ice flow in the Abitibi-Timiskaming region: implications for mineral exploration and dispersal of carbonate rocks from the Hudson Bay Basin, Quebec and Ontario. Geological Survey of Canada, Open File 3033.

Contact: M. Beth McClenaghan, Geological Survey of Canada, 601 Booth Street, Ottawa, Ontario, CANADA, K1A 0E8, Email: bmcclena@nrcan.gc.ca 